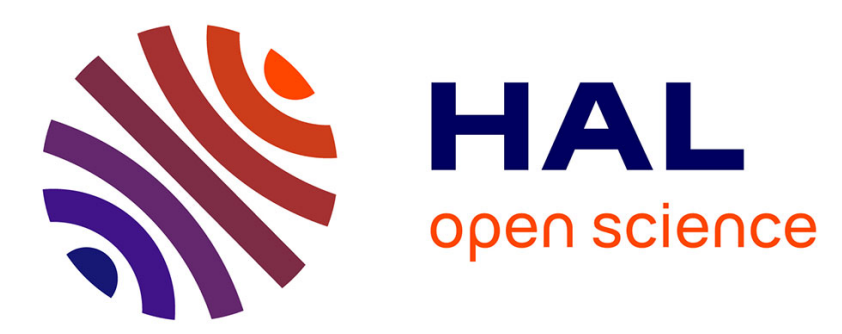

\title{
European Self-Presentations and Narratives Challenged by Islam: Secular Modernity in Question Nilüfer Göle
}

\section{To cite this version:}

Nilüfer Göle. European Self-Presentations and Narratives Challenged by Islam: Secular Modernity in Question. Encarnación Gutiérrez-Rodríguez, Manuela Boatca et Sérgio Costa (dir.). Decolonising European Sociology. Transdisciplinary Approaches, Ashgate, pp. 102-115, 2010. hal-00737717

\section{HAL Id: hal-00737717 https://hal.science/hal-00737717}

Submitted on 2 Oct 2012

HAL is a multi-disciplinary open access archive for the deposit and dissemination of scientific research documents, whether they are published or not. The documents may come from teaching and research institutions in France or abroad, or from public or private research centers.
L'archive ouverte pluridisciplinaire HAL, est destinée au dépôt et à la diffusion de documents scientifiques de niveau recherche, publiés ou non, émanant des établissements d'enseignement et de recherche français ou étrangers, des laboratoires publics ou privés. 


\title{
Decolonizing European Sociology
}

Transdisciplinary Approaches

\author{
Edited by \\ ENCARNACIÓN GUTIÉRREZ RODRÍGUEZ, \\ University of Manchester, $U K$ \\ MANUELA BOATCĂ \\ Catholic University of Eichstätt-Ingolstadt, Germany \\ SÉRGIO COSTA \\ Freie Universität Berlin, Germany
}


(c) Encarnación Gutiérrez Rodriguez, Manuela Boatcă and Sérgio Costa 2010

All rights reserved. No part of this publication may be reproduced, stored in a retrieval system or transmitted in any form or by any means, electronic, mechanical, photocopying, recording or otherwise without the prior permission of the publisher.

Encarnación Gutiérrez Rodríguez, Manuela Boatcă and Sérgio Costa have asserted their right under the Copyright, Designs and Patents Act, 1988, to be identified as the editors of this work.

Published by

Ashgate Publishing Limited

Wey Court East

Ashgate Publishing Company

Union Road

Suite 420

Farnham

101 Cherry Street

Surrey, GU9 7PT

Burlington

England

05401-4405

USA

www.ashgate.com

British Library Cataloguing in Publication Data

Decolonizing European sociology : transdisciplinary

approaches. -- (Global connections)

1. Sociology--Europe. 2. Social sciences--Europe--

Philosophy.

I. Series II. Gutiérrez Rodríguez, Encarnación.

III. Boatcă, Manuela. IV. Costa, Sérgio.

301'.094-dc22

Library of Congress Cataloging-in-Publication Data

Decolonizing European sociology : transdisciplinary approaches / [edited] by Encarnación Gutiérrez Rodríguez, Manuela Boatcă and Sérgio Costa.

p. cm. -- (Global connections)

Includes bibliographical references and index.

ISBN 978-0-7546-7872-4 (hbk) -- ISBN 978-0-7546-9723-7 (ebook)

1. Sociology--Europe. 2. Postcolonialism-.-Europe. I. Gutiérrez Rodríguez, Encarnación.

II. Boatcă, Manuela. III. Costa, Sérgio, 1962-

HM477.E85D43 2009

$301.09182 ' 1--\mathrm{dc} 22$

2009049225

ISBN 9780754678724 (hbk)

ISBN 9780754697237 (ebk)

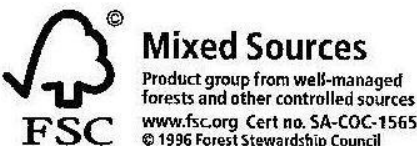

Printed and bound in Great Britain by MPG Books Group, UK 


\section{PART III QUESTIONING POLITICS OF DIFFERENCE}

7 Eurocentrism, Sociology, Secularity

Gregor McLennan

8 Wounded Subjects: Sexual Exceptionalism and the Moral Panic on 'Migrant Homophobia' in Germany

Jin Haritaworn

9 The Perpetual Redrawing of Cultural Boundaries: Central Europe in the Light of Today's Realities

Immanuel Wallerstein

\section{PART IV BORDER-THINKING}

10 Integration as Colonial Pedagogy of Postcolonial Immigrants and People of Colour: A German Case Study

Kien $\mathrm{Nghi} \mathrm{Ha}$

11 The Coloniality of Power and Ethnic Affinity in Migration Policy: The Spanish Case Sandra Gil Araújo

12 Not all the Women Want to be White: Decolonizing Beauty Studies Shirley Anne Tate

\section{PART V LOOKING SOUTH}

13 South of Every North Franco Cassano

14 From the Postmodern to the Postcolonial - and Beyond Both Boaventura de Sousa Santos

15 Critical Geopolitics and the Decolonization of Area Studies Heriberto Cairo 


\title{
Chapter 6 \\ European Self-Presentations and Narratives Challenged by Islam: Secular Modernity in Question
}

\begin{abstract}
Nilüfer Göle
The discipline of sociology, which has shaped the comprehension of modernity as intrinsically a secular process of change, faces today new challenges raised by the revival of religion in general and Islam in particular. European sociology confronts these challenges in a more significant and dramatic way to the extent that Europe becomes a site where particular modes of encounter between the principles of secular modernity and Muslim religious claims are taking place at the level of everyday life practices and are debated in different national publics. In the last three decades, by means of religious claims of Muslim migrants and new controversies in the public life, Islam, an external reference, is becoming an indigenous one in European public life. We can speak of the reterritorialization of Islam in Europe, its "Europeanization" and indigenization which however does not follow a dynamics of assimilation in conformity with European secular modernity. In other words, Islam is becoming contemporary with Europe both in terms of proximity in time and in space (making part of a European "chronotope" [Bakhtin 1978]) but in confrontation with the principles of European secular modernity. "De-centering" European sociology, or displacing the sociological gaze with an anthropological sensibility for difference in non-Western territories and cultural habitations of modernity have helped to engage a critical stand in social sciences (Chakrabarty 2002; Ashcroft 1994). But the present forms of encounter between Islam and Europe take place in the same chronotope (correlation between time and space) without the geographical distance and time lag between the Western colonizer and the colonized, between the modern European and the traditional Muslims, which in turn necessitate framing the relation in terms of transnational and intercultural (read intercivilizational) terms. Consequently, the intimate encounters between Islam and Europe engender a mutual transformation that call for a two-way mirroring and intercultural reflexivity, only possible by means of liberating European narrative of modernity - and sociology - from their colonial frame and universalist claim.

Over the last two decades, the studies on Islam started to occupy a central place on the social science agenda. Such a resurgence of interest in Islam is related to the
\end{abstract}


revival of religious claims and movements that have transformed the political and public scene in Muslim-majority countries as well as in Western contexts. The use of Islam as a reference for the self-presentation by diverse social groups such as youth, women and migrants in the contemporary world poses a challenge to the Western narratives of secular modernity. With the emergence of contemporary forms of Islam that range from the Iranian revolution and women's veiling to jihadist movements, studies on Islam cease to be a field reserved exclusively to Orientalists, theologians or area studies specialists and move to the center of the research agenda of political sciences, sociology, anthropology, and law. Increasingly, interdisciplinary approaches are used to study contemporary forms of Islamic religiosity and agency. The entry of Islam on the research agenda brings forth new horizons of critique in social scientific agenda. We can speak of a new configuration of "Islamic studies" that unsettles the disciplinary frontiers and opens-up critical readings of European modernity and sociology from the vantage point of Islam.

Whether Islamic studies can have an impact on introducing the vantage point of the "subaltern" Muslim and decolonizing European sociology. Whether universalist claims of European sociology can give way to new ways of articulating secularity and modernity and therefore contribute to the "opening of the social sciences" (Wallerstein et al. 1996). All emerge as questions that need to be addressed. Indeed Islamic studies increasingly expand to different disciplines and transform their research agenda. I will evoke three major, broad and cutting edge research topics, namely, globalization, the public sphere, and gender, in order to elaborate on the ways Islam enters on these research agendas and thereby unsettles the established frames of thought. I use the notion of Islam to the extent that Muslim actors in their present day practices articulate their faith and agency in ways that challenge Western hegemony on definitions of modern global order, European public life and gendered self.

The contemporary forms of Islam are studied and framed differently depending on whether the emphasis is on religion, modes of governance, social norms and values, or on modes of mobilization and confrontation. Different conceptualizations, such as religious revivalism, Islamic Sharia, cultural conservatism, terrorist-jihadist movements, and the "clash of civilizations", all designate the cross-disciplinary efforts to depict and comprehend the contours of contemporary Islam. However, the latter raise problems of conceptualization and labeling. Islamic Studies have in fact attempted to name and conceptualize the imprint of Islam in the actions and interpretations of diverse actors. The notion of Islamism has had an advantage of establishing a distinction between Islam as a religion and its forms of political radicalization. The political science approaches to Islam have allowed us to understand contemporary forms of religious contestation that are not separable from the mobilization of masses, the seizure of state power and the application of Sharia law. Nonetheless, political science approaches have tendency to reduce the role of religion to its instrumentalization by groups of political power. Anthropological approaches, on 
the other hand have underscored the importance of faith, studied the formations of religious subjectivities yet dissociated them from questions of agency and social problems. Sociological studies provided depictions of the role of urban groups, educated youth, women and intellectuals in Islamic movements, but remained within the limits of the state vs. society dichotomy. The study of contemporary Islam calls for depicting the diversity of praxis and the transnational dynamics in which Islamic religion is reinterpreted and reactivated with the aim of shaping the intimate, public and political lives of Muslims. Islamic movements do not merely target juridical governance and political life, but equally affect the public and private spheres, that is to say, gender regimes, social morals and spatial arrangements. The complexities of contemporary Islamic modes of expression and the new re-compositions between faith and agency, secular and religious, personal and public requires an interdisciplinary approach but furthermore a critique of the already established frames of Western sociological thought.

As sociological theories about secularization undergo a critical revision, the studies on the "return of religion" have gained a real interest. The two pillars on which the narrative of modernity was constructed, namely, secularization and the idea of progress, are challenged by the concomitant desire for the return of religion and for the forces of the immutable (Dozon 2007). However, contemporary Islam is far from being a continuation of the chains of the historical past, and witnesses on the contrary a radical rupture and change. The imprint of the past, the religious and the traditional can only be captured within the prism of contemporary social forms of criticism and contestation. The Islamic movements are "rejuvenated" by the adherence of young and educated urban populations and "feminized" by the presence of girls and women that have begun to take on the veil since the 1980s (following a period of unveiling in the 1920s, in conformity with the secular reformist movements of elites in many Muslim countries such as Turkey, Iran and Egypt). The revival of Islam means for many of its young and female followers a relearning of religious knowledge, studying the precepts, and rethinking the present issues from the prism of the religious past. The immutability promised by religion and the power of its long durée history create a veritable magnetism for those who seek guidance in a world governed by "presentism" (Hartog 2003). Islamic fundamentalism revalorizes the golden age of Islam, drawing on a model in the past, rather than an unrealized ideal, a utopia. The text of the Koran and the life of the Prophet Muhammad serve as guidelines and sources of example for sorting out the grammar of leading a "truly" pious existence at the level of everyday life practices as well as for finding the right path in modern life.

Hence, framing contemporary Islam as the "return of religion" reveals to be a more complex phenomenon than it appears. The notion of "religion" embodies and carries a plethora of meanings and praxis that requires unpacking and criticism in the light of practices and interpretations of contemporary actors. Islam(ism) is the name that refers to the conscious and collective ways of refashioning religion from the prism of contemporary issues in modern life politics and in a globalized 
world. In doing so, contemporary Islam enters on the historical stage of the present in debating and confronting the Universalist claims of secular modernity and European social thinking. The entry of Islam into the realm of global politics, European publics and sexual modernity, unsettles the established power relations and frames of thought. The three realms correspond to three different scales on which Western modernity disputes over its hegemony, namely over the rules of the world order, the morals of the public life, and the sexual norms of the self. The three realms and scales operate on different temporalities but they exemplify the most central sites in tracking and debating the changes of Western European modernity. The social scientific agenda in general and sociology in particular search for understanding the new patterns of globalism and transnational dynamics, the cultural and religious difference in the public sphere and the forms of sexual emancipation and feminism. Islamic studies enter these three pioneer areas and transform the intellectual agenda in challenging the definitions of transnational publics and self.

First, one has to be reminded that studies on globalization and Islam came to be related only recently, especially in the aftermath of $9 / 11$. There is an increasing awareness that Islam cannot be studied as if it were confined to political dynamics within a given nation-state (as was the case with the Islamic revolution in Iran in 1979); neither can it be identified with one single region (such as the Middle East). It circulates among different publics, nations and regions and becomes a global affair whether it is related to the phenomenon of immigration, to public controversies, or to terrorist acts. Secondly, Islam becomes public, meaning that religion, which is supposed to be contained within the private domain, claims visibility in the public arena. Thirdly, questions of gender and sexuality are central in the course of contemporary Islamism but also in the process of confrontation with European publics. The Islamic veiling in public is a sign of transgressing spatial and gendered boundaries of the sacred private domain. Furthermore, staging the Islamic difference by means of the symbolism of the veil in the European public spheres carries an ambivalent message: Muslim women claim their access and presence in the secular public life yet provokes a discord in unsettling the tacit rules and cultural codes of European public life.

The controversies on Islamic headscarves of Muslim students in French public schools or of teachers in Germany ${ }^{1}$ indicate clearly the way Islam ceases to be a Muslim-Muslim question and becomes a concern for European public. Contemporary Islam provokes cultural "malaise", mobilizes collective passion to the extent that the very foundations of secular modernity is thought to be threatened by the religious claims in public life. Islam is perceived as a threat to the most contemporary and highly valued achievements of European liberal democracies, such as sexual liberation, gender equality and the freedom of expression. The public presence and staging of Islam in European democracies

1 For the French and German controversies see Amir-Mozami 2004, Bowen 2007 and Scott 2007. For the British context, see Joppke 2009. 
trigger a debate on the presence of Muslims in Europe, and well beyond that, on the cultural values of Europe. In the course of these debates, the values that govern the public order (secularism, freedom of expression and tolerance) as well as the ones concerning the private or personal sphere (women's status, religious faith) come to be confronted with one another and then renegotiated, bringing about a displacement of boundaries between public and private, secular and religious, and Europe and Islam.

\section{Islam on the Global Scene}

The process of globalization brings people and cultures in closer contact. The anthropological distance and the frontiers between the self and the others, between the moderns and the indigenous, between the colonizers and the colonized are blurred, if not erased within an increasingly interconnected globe. The reduction of time and space between different parts of the world brings together cultures, countries and people, however not necessarily creating a better understanding between cultures. Globalization accelerates the speed with which information, goods, and people circulate among different publics, markets and nations, but the blurring of frontiers equally provokes national anxieties, social frictions and cultural clashes. These propositions are also valid for Islam.

Globalization does not stop short of changing the lives and minds of Muslims; but furthermore Islam becomes an active component in the acceleration and amplification of globalism. Political Islam does not operate exclusively on a national scale, but enters into a new phase of circulation at a planetary scale. In an earlier phase, the politicization of Islam, that has led to the Iranian Revolution of 1979 was studied on a national scale as a mode of popular mobilization inspired by an ideology and a religious lexicon that condemn the authoritarian and "impious" powers of the Middle East. Islamic radicalism was explained as an outcome of several factors, such as immigration, economic poverty and political regimes, as a "reaction" to a situation of "crises". The vertical relations of power between state and society were privileged in this earlier phase of Islamic studies. However, the scale of analysis shifted to a more transnational and global one following the terrorist attacks of 9/11 in 2001 that marked a turning point in the analysis of "global Islam" (Roy 2002). Mainly the terrorist dimensions of Islamic movements are explained in conformity with the forces of globalism. The jihadism of Al-Qaeda is taken to be the most dramatic illustration of globalized Islam; its nebulous mode of organization, the profile of its terrorist-martyrs, the transnational life-trajectories in their military training, as well as the targets of attack can all be seen as the product of a transnational logic. The global imprint is quite obvious in the logic of terrorist acts or in the life trajectories of the terrorists. However, the jihadist attacks did not only follow and profit from global dynamics, but also in an unexpected and unwilling way brought the United States to join the global world and suffer its destructive effects (Göle 2002a). 
The centrality of the notion of "umma", the community of believers in the Islamic faith, predisposes Muslims to think and act beyond national borders, i.e., globally. Although it is quite unrealistic to evoke a unified Muslim community at a moment in history when confessional differences and national interests continue to divide Muslims (Kepel 2004), contemporary Islamism does participate in the production of a common imaginary. It elaborates itself by mutual borrowings and hybridizations: the traditions and norms of a confession (such as the martyr figure in the Shiite tradition) are continuously re-adapted and transformed by those of other confessions, hence producing a religious and political syncretism (Khosrokhavar 2003). One might argue that the production of Islamic social imaginary takes place through micro-practices, performative and visual acts that circulate between different publics and take roots in different national contexts (Göle 2002b). It is possible to sort out a mapping of an Islamic imaginary following a series of constitutive events that provide a common reference, repertoire of action and collective memory. The formation of an Islamic imaginary transgresses national boundaries and pre-established confessional distinctions; it works as a collage, an assemblage bringing together distinct elements, composing with different fragments and producing a new pattern of action. Globalization accelerates the elaboration of a social religious "imaginary" and its promises, providing a virtual sense of belonging, a social bondage even between those who do not share the same communitarian, confessional or national distinctions. The "sorority" between veiled women or the "fraternity" between martyrs - even though they represent two very distinct and opposing forms of religious agency and religious figures - pious-self or self-sacrifice - embody the micro practices constitutive of this imaginary.

The notion of social imaginary (Taylor 2004) is elaborated by means of religious performances, symbols, and narratives; it is mediated by means of a visual and popular culture. Islamic social imaginary is shaped by religious piety, memory and a repertoire of action that is both religiously and politically oriented among actors who are connected to each other by religious and "imaginary" ties, forming an "imagined community" (Anderson 1991). The radicalization of Islamic political movements in the end of 1970 s was closely related with a new ideological framework that was elaborated by thinkers and ideologists of Islam. These authors were widely translated and read by the generation of Muslims who have followed the ideas of politicization of Islam and embraced the criticism addressed to orthodox religious thinkers ("ulema"). But in distinction from Islamic theology and ideology, both being shaped by the knowledge of few, by a group of theologians and political activists, Islamic social imaginary is shaped by new forms of visual and performative culture and is shared by persons and groups who do not have necessarily a sense of belonging to a political structure or to a religious institution. However globalized forms of Islam participate in the elaboration of a religious imaginary and cultural performance that unsettles and challenges the European secular imaginaries and gendered performances. 
If the political and the national are not the decisive mediators of conflict and consensus, how can we frame the question of religious and cultural difference? The debates on globalization necessitate a rethinking of the place of the national (Calhoun 2007), but likewise of the public sphere.

\section{Islam in Public}

The nature of the relationship between the political and the public spheres, their mutual interdependence undergoes a change with the impact of globalism. By means of global communication networks, the public sphere, participates in a transnational realm, whereas the political sphere is constrained and confined within the boundaries of a nation-state. Globalization instigates the autonomization of the public vis-à-vis the political realm. Whereas publics have the tendency to become transnational, politics remain national.

The public domain hence becomes the privileged site for the manifestations of a globalized Islam in Europe (Allievi and Nielsen 2003). The search for the public visibility of religion triggers public controversies in different national contexts and across the borders. Islam participates in the formation of a transnational European public, but in confrontation with the norms and morals of European secular modernity. The emergence of a transnational public space is accompanied by the deepening of the cleavages: national publics, cultural codes and religious referents are brought in spatial proximity while cultural differences are at the same time staged, accentuated and amplified by symbols, clichés or grotesque images. In the age of globalism, the public sphere favors circulation rather than mediation (whether political, intellectual or artistic), the figural rather than the textual, the affective, sensorial and scandalous rather than the rational and discursive. Hence symbols, images, icons or cartoons travel faster than words, penetrate personal and collective imaginaries, and propagate by amplification of their significations and perceptions. The public sphere becomes the site for the confrontational proximity and co-penetrations between different Muslim and "European" cultural and religious codes.

In late modernity, the spectacular and the visual figural attributes of public communication are privileged. New forms of Islamic agency follow and furthermore amplify the performative, symbolic, sensorial and affective dimensions of expressing religious difference. Islam is staged in public by means of religious rituals and symbols, by gendered modes of address, by manifestations and collective prayers, and by new forms of jihadism and violence that challenge and threaten the consensual values and civilizational attributes of Europe. These acts and agencies, less discursive and more performative, employ a sort of grammar of silence, a non-verbal communication and yet have the power of provoking and unsettling the established relations of cultural difference and power.

A new frame of thought is necessary to conceptualize the ways European publics relate to Islamic difference. It necessitates unsettling the hegemony of the 
European self-presentation and conceptualization of a transversal bond without excluding the role of the confrontation, violence and discord; namely a process of "interpenetration" between the two in which the definitions of sexuality and the sacred plays a central role (Göle 2005).

A mapping of events, incidents and controversies can highlight the zones of contact and confrontation, the zones that we can also designate as "frontier spaces" (Sassen 2006) between Europe and Islam. The fatwa against Salman Rushdie, the public debate on the Islamic veiling in France, Ayan Hirsi Ali's film on "Submission" and the assassination of Theo Van Gogh, the cartoon controversy in Denmark, the attacks of Al-Qaeda in the European cities and the debates on the Turkish candidacy to the European Union are all examples of the antagonistic nature of this encounter. Each of these events, in different ways, has carried Islam into European publics and provoked a larger debate on the cultural values and frontiers of Europe in distinction with Islam; ranging from the place of religion in public life, principles of secularism, freedom of expression and gender equality.

The relationship that has been established between an ideal-public sphere and the functioning of a pluralistic democracy, particularly in the work of Jürgen Habermas, has been revisited from an interdisciplinary perspective in view of a more pluralistic conceptualization of the public sphere. The critiques of the public sphere have demonstrated the ways the latter reassembles and includes as well as the way it excludes by means of drawing boundaries and establishing criteria of access in terms of education, class, age, gender and race. However Islam has been disregarded in these conceptualizations of the public sphere (Habermas $1992 ; 2002$ ). Adding Islam on this list does not imply simply the broadening of the boundaries of the public sphere. The irruption of Islam within European publics reveals new boundaries of exclusion but also the public doxas, namely a set of shared secular imaginaries and feminist presuppositions that are constitutive of the contemporary European public mind. Islam carries religion into public life and disrupts the pre-established boundaries between privatized religion and public rationality on the one hand and gendered definitions of agency on the other hand. The Islamic veiling of the young school girls disrupts the criteria of age, education and gender in proscribing access to public citizenship and debate. The arguments that have favored the ban of the religious signs in French public schools were based generally upon the denial of agency (they are minor) and individuality of Muslim girls (they are religious) in adopting the headscarf. Furthermore, fathers, brothers, militant Islam or the community pressure are designated as the oppressor behind the symbol of the veil. Secular narratives of modernity have expected religion to withdraw into the private realm and disappear as an actor of change, of history. Consequently, the definitions of citizenship rights - namely, equal access to the public sphere, freedom of expression, liberty and agency - are all thought to be the outcome of secular formations of individualism and power. Muslim women's claim for religious covering disrupts the equation between secularism and political agency, but also between feminism and emancipation. Religious gendered agency reveals a series of ambivalences - faith and agency, woman and public life, age 
and decision - that can not be acknowledged within the secular European frames of thinking in terms of "either-or" categories (either religious or secular, either feminist or Islamist, either European or Muslim). Public Islam blurs and unsettles not only the personal-public frontiers, and religious-secular oppositions, but moreover brings forth new borrowings, mixings, re-compositions between these binary oppositions.

\section{Sexuality and Islam}

In shifting the boundaries between the personal and the political, contemporary Islam ironically joins Western feminism in many ways. The realm that is considered to be closest to the personal, corporal, intimate and sacred is carried into public life; wearing religious symbols in public schools, construction of mosques in European cities, dietary regimes in cafeterias, Islamic holidays, rooms for prayer in work settings, all examples that inscribe a religious imprint in the European public spaces. The European presence of Islam takes religion into the agenda of politics, but more profoundly unsettles the established boundaries between the private and the public. A religious reminder of the personal, private and public makes its way into new agencies and imaginaries. A sacred notion of the private parts of the body and space is at work in modern public life; a process that I have designated as "modern-mahrem", as this Arabic word "mahrem" signifies the interior, sacred, gendered space which is both spatial and corporeal (Göle 1996).

The veiling of women is a reminder of an alternative ways of linking femininity and sexuality in public. While feminine traits are expressed and distinguished from male outlook and male appearances (veiling is supposed to set a difference from male dress codes), woman's sexuality is contained within the values of modesty. In contrast, the secular feminist modes of self-fashioning blurs gender differences by borrowing from men's clothing and appearance (unisex and short hair as emblems of feminism) and expose the liberty of sexual disposition and interaction with the other sex. The opposition and confrontation between two figures of women, reveal the differences of corporeal management of feminity and sexuality in public life. The battleground involves alongside the orientation of ethical values that of esthetical ones. Inventions of new modes of Islamic covering point to the changes in the domain of fashion, through which new elaborations between beauty, feminity and sexuality are manifested.

The question of woman and sexuality occupies a central place in these controversies because late modernity is shaped by gender equality and by emancipatory regimes of body and sexuality. The European self-fashioning and self-presentation embodies the equality of gender relations, between women and men as well as between persons of the same sex. In the eyes of the European publics, Islamic veiling as a symbol of religious submission and gender segregation becomes a reminder of a pre-feminist past. However the veiling is carried into public life by young women who by means of education and political engagement 
have distanced themselves from traditional roles of women and found themselves in social mixing with men. The veiling publicly stages a form of feminine personality and sexuality that enters into confrontation with the European self-presentations of woman and secular modernity. Islamic veiling is contemporary with secular feminism and yet in oppositional distinction with the pre-established norms of secular emancipation.

For the feminists of post-1968, the body was central in the struggles for emancipation of women (as the slogan "our bodies belong to us" illustrates); a body liberated from the chains of biological difference (the right for abortion and contraception), from sexual violence and harassment, and from the male desire and gaze; a body that was taking its revenge by displaying its new liberty in public. Feminism has profoundly altered not only the relationship between women and men, but also the relationship of women with their own bodies. This process is also synonymous with the entrance of women's bodies in the spiral of an accelerated secularization in which the culture of "care of the self", "pleasing one's own self" and "taking good care of one's body" show that the body has not only turned into a place of cult for personal liberty, but also become conform with the imperatives of neo-liberalism. Yesterday's rights to contraception and abortion and today's "genetic engineering" have displaced the realm of reproduction from the universe of natural constraints to that of personal choice, thereby shifting the cursor from nature towards culture. This process is an undeniable sign of a larger personal liberty and plurality of options of choice in life, but also opens up significant questioning in moral and ethical terms. The "return of religion" in contemporary world is not a relic of the past but an indicator of the contemporary problems and limits raised by late or ultra-modernity.

Religion in general and the act of veiling in particular recall the submission of the self to divine will, and valorize the feeling of humility against the will of the secular and omnipotent modern subject. Once more it is woman's body - as the marker of values of modesty or pleasure, submission or emancipation - that comes to intersect the patriarchal power relations and the confrontation among religious and secular women. In other words, the Enlightenment project can be read as an incessant displacement of the frontiers between nature and culture, progressively displacing the realm of religion, reproduction and nature into the domain of the cultural and thus turning religion into a matter of individual choice; woman's body follows the imperatives of this meta-project and delineates the cursor between the religious and the mundane, the patriarchal and the personal, the natural and the cultural.

In the act of wearing the Islamic veil, one can read a critique addressed to the logic of extreme emancipation, in which the body is the locus. Without always being the master of the signification of this act, a woman that covers her hair conveys a sense of preservation of self, a resistance to the spiral of secularization - a spiral that encompasses all domains of life from procreation to aesthetics, and that offers a distressing promise of incessant changes and innovations. In counter distinction with Western woman's body - considered as a symbol of aesthetic 
prestige and liberty, an object of idolatry - Muslim women re-introduce in their subjectivity a part of abstraction through obedience to the divine order, to religious rituals and constraining mundane and carnal pleasures. (The training of the nafs - an Arabic word that means the flesh, the spirit of concupiscence, and symbolizes the carnal impulses - so as to make it obedient to pious impulses is central for the construction of Muslim subject).

Islamic veiling allows Muslim women to make their appearance on the public scene as much as it conceals and confines them. It accentuates the battle of social mores by means of adopting performative but silent/nonverbal communication. It is the incarnation of Islamic religious precepts, of the social grammar of interdiction between the gaze and the body as well as of the exposition of what is at stake in clothing and effects of "stylization". Georg Simmel argues that clothing is an "appeasing response to the exaggerated subjectivism of the époque, the place of 'retreat', of individual's taking distance and a manifestation of a sense of modesty and discretion" (Simmel 1998). For clothing is about the connection of particular to the general, the personal to the impersonal, and the subjective to the inter-subjective. It distinguishes and creates a distance as much as it allows the individual to enter into a form that is shared by the others. It is with these modern ways of clothing that the veiling is situated in this "in-between-ness": it is both "modern and Muslim" (Göle 1993; 2003). Being a modern Muslim is a state of being "in-between" because it reveals both proximity and alterity through the clothing of emancipated religious women and thus seeks to subvert the aesthetical definition of femininity and that of subjectivity.

Islamic Studies are inseparable from the studies on modernity in its multiple, alternative and non-occidental forms. The more the definition of modernity is separated from the Enlightenment paradigm, the more our reflection opens up on the new forms and criticisms that modernity takes on today. This fact weakens the Western narratives on modernity at work in the social sciences today. While at the same time it blurs the frontiers between the social sciences of the "other" (Orientalism, Area Studies, Anthropology, Postcolonial Studies) and the social sciences of the (Western) "self" (History, Sociology, Political Sciences and Feminism). Islamic Studies is at the heart of this metamorphosis in social sciences: it is both subject and instigator of this transformation. The gendered, public and global manifestations of Islam challenge the studies on Islam to open up a new space for reading Western modernity and decolonizing European sociology. Islam and Islamic studies can be thought as a necessary antinomy, as the "constitutive outside" (Derrida 1991) to the public doxas of secular-sexual modernity. To the extent they contribute to the unpacking of these Eurocentric doxas of sexual norms, public morals and global order, Islamic studies have the potential to subvert social scientific agenda and reorient social criticism. 


\section{References}

Allievi, S. and Nielsen, J.S. (eds) 2003. Muslim Networks and Transnational Communities in and Across Europe. Leiden and Boston: Brill.

Amir-Mozami, S. 2004. Discourses and Counter-Discourses: The Islamic Headscarf in the French and German Public Spheres. Unpublished PhD Dissertation. Florence: European University Institute, Department of Political and Social Sciences.

Anderson, B. 1991. Imagined Communities: Reflections on the Origins and Spread of Nationalism. London and New York: Verso.

Ashcroft, B. (ed.) 1994. The Post-colonial Studies Reader. London: Routledge.

Bakhtin, M. 1978. Esthétique et théorie du roman, translated by Daria Olivier. Paris: Gallimard, 384-50.

Bowen, J.R. 2007. Why the French Don't Like Headscarves: Islam, the State, and Public Space. Princeton: Princeton University Press.

Calhoun, C. 2007. Nations Matter: Culture, History and the Cosmopolitan Dream. New York: Routledge.

Chakrabarty, D. 2002. Habitations of Modernity: Essays in the Wake of Subaltern Studies. Chicago: The University of Chicago Press.

Derrida, J. 1991. L'Autre Cap. Paris: Les editions de Minuit.

Dozon, J.P. 2007. Les Temps des retours, in Les Sciences Sociales en Mutation, edited by M. Wieviorka. Paris: Editions Sciences Humaines, 371-8.

Göle, N. 1993. Musulmanes et Modernes. Paris: La Découverte (Second Edition 2003, La Découverte Poche).

Göle, N. 1996. The Forbidden Modern: Veiling and Civilization. Ann Arbor: University of Michigan.

Göle, N. 2002a. Close Encounters: Islam, Modernity, and Violence, in Understanding September 11, edited by C. Calhoun, P. Price and A. Timmers. New York: The New York Press, 332-44.

Göle, N. 2002b. Islam in Public: New Visibilities and New Imaginaries. Public Culture, 14, 173-90.

Göle, N. 2005. Interpénetrations: L'islam et l'Europe. Paris: Galaade Editions.

Göle, N. 2007. L'islam à la rencontre des sciences sociales, in Les Sciences Sociales en Mutation, edited by M. Wieviorka. Paris: Editions Sciences Humaines, 417 26.

Göle, N. and Amman, L. (eds) 2004. Islam in Sicht. Der Auftritt von Muslimen im öffentlichen Raum. Bielefeld: Transcript (published in English 2006. Islam in Public. Istanbul: Bilgi University Press).

Habermas, J. 1992. Droit et democratie, Entre faits et norms, translated by R. Rochlitz and C. Bouchindhomme. Paris: Gallimard.

Habermas, J. 2002. Apres l'Etat-nation, Une nouvelle constellation politique, translated by Rainer Rochlitz. Paris: Fayard.

Hartog, F. 2003. Regimes d'historicité. Paris: Seuil.

Joppke, C. 2009. Veil: Mirror of Identity. Cambridge and Malden: Polity Press. 
Kepel, G. 2004. Fitna, guerre au coeur de l'islam. Paris: Gallimard.

Khosrokhavar, F. 2003. Les nouveaux martryrs d'Allah. Paris: Flammarion.

Roy, O. 2002. L'Islam mondialisé. Paris: Seuil.

Sassen, S. 2006. Territory, Authority, Rights: From Medieval to Global Assemblages. Princeton: Princeton University Press.

Scott, J.W. 2007. The Politics of the Veil. Princeton: Princeton University Press.

Simmel, G. 1998. La parure et autres essais. Paris: Maison des sciences de l'homme.

Taylor, C. 2004. Modern Social Imaginaries. Durham and London: Duke University Press.

Vinas, F. 1998. Entre oui et non: Simmel, Philosophe de l'Ame moderne, La parure et autres essais. Paris: Editions Maison des Sciences de l'Homme.

Wallerstein, et al. (eds.) 1996. Open the Social Sciences: Report of the Gulbenkian Commission on the Restructuring of the Social Sciences. Stanford: Stanford University Press. 
